Biological and Clinical Sciences Research Journal

ISSN: 2708-2261

www.bcsrj.com

DOI: https://doi.org/10.54112/bcsri.v2020i1.33

Biol. Clin. Sci. Res. J., Volume, 2020: 33

Original Research

\title{
ANTIBACTERIAL AND ANTIFUNGAL ACTIVITY OF FRUIT, SEED AND ROOT EXTRACTS OF CITRULLUS COLOCYNTHIS PLANT
}

\author{
HAMEED B, *ALI Q, *HAFEEZ MM, MALIK A
}

\author{
Institute of Molecular Biology and Biotechnology, The University of Lahore, Lahore, Pakistan \\ Corresponding author email: mansoorhafeez140@gmail.com, saim1692@gmail.com
}

(Received, $12^{\text {th }}$ June 2020, Revised $26^{\text {th }}$ September 2020, Published $29^{\text {th }}$ September 2020)

\begin{abstract}
Gastrointestinal, skin, pulmonary and cardiovascular problems have been reported all over the world on massive scale. The treatment of these problems has become tough due to genetically modified bacterial strains and fungal infections. The present studied was conducted to evaluate the antimicrobial activities of Citrullus colocynthis plant extract. The ethanolic extract of dried fruit pulp, seed, and root was evaluated with respect to anti-bacterial and anti-fungal properties. The anti-microbial profile studied against four bacterial strains (2 Gram negative and 2 Gram positive) while anti-fungal profile studied against four fungal species. All the bacterial and fungal strains used in the study showed sensitivities against the respective extracts. The zones of inhibition ranged between $7 \mathrm{~mm}$ to $23 \mathrm{~mm}$, and $6 \mathrm{~mm}$ to $23 \mathrm{~mm}$ in against bacterial and fungal strains, respectively. The extract of seed found to be less effective against both the organisms. It was suggested from our study that the extract of Citrullus colocynthis may be used in medicines to cure bacterial diseases.
\end{abstract}

Keywords: Citrullus colocynthis, antifungal, antibacterial, fruit pulp, seed, root, zones of inhibition

\section{Introduction}

Citrullus colocynthis plant belongs to the family Cucurbitaceae. It contains one of the outstanding collections of the genetically diversified organisms in the kingdom of plants. A large number of plants of this family are drought tolerant, susceptible to flooding, cold season and resistant to harshness of barren lands (Dhakad et al., 2017; Kapoor et al., 2020). Citrullus colocynthis plant is an herb which shows perennial mode of life. The herbs are commonly found drawn along the ground or other surface commonly found in desert lands of Punjab and Sindh in Pakistan and central and southern areas of India (Bhasin et al., 2020; Yazit et al., 2019). Besides, Arabia, West Asia, Mediterranean and Tropical African regions are home for it. Its tendrils are not so complex, 2-3 feet fine with hair like projections on them (Kouadri and Satha, 2018; Riaz et al., 2015). Leaves are round and positioned alternatively on the leafstalk. Each leaf is about 4 to 9 centimeters in long and contains nearly 4 to 7 lobes on it with rough and hairy appearance showing bright green color on the upper while pale green on the lower surface of the leaves. Seeds contain a big range of fatty acids like stearic acid, myristic acid, palmitic acid, oleic acid, linoleic acid and linolenic acid (Davidovich-Rikanati et al., 2015; Pravin et al., 2013). The protein portion is abundant in amino acids like lysine, leucine and methionine. It also contains vitamins B1, B2 and niacin. Minerals like calcium, magnesium, potassium, iron and manganese are also present (Gurudeeban et al., 2010; Hussain et al., 2014). The aerial part and fruit contains flavonoid glycoside quercetin, flavone-3-glucoside viz isovitexin, iso-orentine and iso-orentine-3-methyl ether (Dastmalchi et al., 2007; Sharififar et al., 2007). The fruit contains a complex amount of Cucurbitane type triterpine glycoside viz colocynthoside $\mathrm{A}$ and $\mathrm{B}$. Cucurbitane type triterpene glycoside ciz cucurbitacin E 2-O-beta-D-glycoside its aglycone Cucurbitacin E and 2-O-beta-D-glycopyranosylcucrbitacin B and 2,25-di-O-beta-D-glycopyronasylcucurbitacin L (Davidovich-Rikanati et al., 2015; Song et al., 2015).

The importance of $C$. colocynthis plant is disclosed in certain studies as it has various medicinal effects. Anti-inflammatory effect (Onyeji et al., 2017), antioxidative effect (Bernard and Olayinka, 2010), anticonvulsant effect (Kaushik et al., 2015; Mehrzadi et al., 2016), anti-alopecia effect (Dhanotia et al.,

[Citation: Hameed, B., Ali, Q., Hafeez, M.M., Malik, A. (2020). Antibacterial and antifungal activity of fruit, seed and root extracts of Citrullus colocynthis plant. Biol. Clin. Sci. Res. J., 2020: $33 . \quad$ doi: https://doi.org/10.54112/bcsrj.v2020i1.33] 
2011), anti-fungal effect (Rezai et al., 2017; Salehi et al., 2019), and anti-diabetic effect (Jayaraman et al., 2009). In our study, anti-microbial and anti-fungal activities of ethanolic extracts of Citrullus colocynthis plant were studied using the fruit pulp, seeds and roots of matured plant.

\section{Materials and methods}

\section{Extract preparation}

Citrullus colocynthis fruits and roots were collected from local areas in Lahore, Pakistan. Roots and fruits were dried under sunlight. Seeds were separated from dried fruits. Fruit pulp, seeds and roots were converted into powdered form. About 70 grams of samples were taken into powdered form and were soaked into $250 \mathrm{ml}$ of ethanol as a solvent. The crude preparation was left for a week and filtered. The filtrate thus separated was dried using rotatory using at high pressure and temperature. The crude extracts were weighed, and were dissolved into known volume of dimethyl sulfoxide or DMSO as a solvent to obtain required concentrations of $25 \mathrm{mg}, 50 \mathrm{mg}, 75$ $\mathrm{mg}$ and $100 \mathrm{mg} / 1 \mathrm{ml}$ DMSO.

\section{Test microorganisms}

Four species of bacteria and four species of fungi were acquired to be used in the study from microbiology lab of the University of Lahore. Two species were Gram positive while other two species were Gram negative. Bacterial species were included gram positive Staphylococcus aureus and Bacillus subtilis, Gram negative Pseudomonas aeruginosa and Klebseilla pneumonia. Fungal species were included Fuserium oxysporum, Candida albicans, Aspergillus fumigatus and Aspergillus niger.

\section{Antibacterial assay}

For antibacterial activity, well diffusion method and disc diffusion method were followed (Bauer et al., 1966). For inoculation, bacterial stock cultures prepared in glycerol were used. Muller Hinton agar plates were seeded with bacterial cultures. Wells were cut for applying well diffusion method and 10 $\mu l$ of plant extracts (fruit pulp, seed and root extracts with different concentrations) were poured. For applying disc diffusion method, discs soaked with extracts and positive and negative control were put on the culture plates and all the plates were incubated at $37^{\circ}$ Celsius for $22-24$ hours. After the incubation period, diameter of the zones of inhibition was measured. Ciprofloxacin was used as a positive control.

\section{Antibacterial assay}

For antifungal assay, cultures of fungus were made by growing the fungal strains in Sabouraud's dextrose agar plates. Plates were seeded with fungal strains and then discs of extracts (fruit pulp, seed and root with different concentrations) and negative control and positive control (fungi zone discs $15 \mu \mathrm{g}$ per disc) were placed on the plates by using sterilized forceps. All the plates were incubated at $25^{\circ}$ Celsius for 24 hours. Results were noted and zones of inhibition were measured.

\section{Result}

The results showed that all bacterial and fungal strains were sensitive against the extracts of fruit pulp, seed and root of Citrullus colocynthis (Figure 1, Tables 1-6). The results indicated that ethanolic extract of fruit pulp of $C$. colocynthis show activity against Gram-positive bacteria significantly than Gram-negative bacteria. Table 1 shows maximum activity of $S$. aureus from $11 \mathrm{~mm}$ at $25 \mathrm{mg} / 1 \mathrm{ml}$ of DMSO to $22 \mathrm{~mm}$ at concentration of $100 \mathrm{mg} / 1 \mathrm{ml}$ DMSO. The results from table 2 showed highest zone of inhibition against $A$. fumigatus from $10 \mathrm{~mm}$ (at 25 $\mathrm{mg} / 1 \mathrm{ml}$ DMSO) to $19 \mathrm{~mm}$ (at $100 \mathrm{mg} / 1 \mathrm{ml}$ DMSO). The table 3 shows highest zone of inhibition of root extract of $C$. colocynthis against $B$. subtilis $11 \mathrm{~mm}$ (at $25 \mathrm{mg} / 1 \mathrm{ml}$ DMSO) and $23 \mathrm{~mm}$ (at $100 \mathrm{mg} / 1 \mathrm{ml}$ DMSO). The results form table 4 shows highest zone of inhibition against A. fumigatus $11 \mathrm{~mm}$ (at 25 $\mathrm{mg} / 1 \mathrm{ml} \mathrm{DMSO}$ ) and $21 \mathrm{~mm}$ (at $100 \mathrm{mg} / 1 \mathrm{ml}$ DMSO). The table 5 shows highest zone of inhibition of seed extract of $C$. colocynthis against $B$. subtilis $11 \mathrm{~mm}$ (at $25 \mathrm{mg} / 1 \mathrm{ml} \mathrm{DMSO}$ ) and $22 \mathrm{~mm}$ (at $100 \mathrm{mg} / 1 \mathrm{ml}$ DMSO). The table 6 shows highest zone of inhibition against $F$. oxysporum $15 \mathrm{~mm}$ (at $25 \mathrm{mg} / 1 \mathrm{ml}$ DMSO) and $21 \mathrm{~mm}$ (at $100 \mathrm{mg} / 1 \mathrm{ml}$ DMSO). Both the bacterial and fungal strains showed greater zones of inhibition by increasing the concentrations of the extracts.

[Citation: Hameed, B., Ali, Q., Hafeez, M.M., Malik, A. (2020). Antibacterial and antifungal activity of fruit, seed and root extracts of Citrullus colocynthis plant. Biol. Clin. Sci. Res. J., 2020: $33 . \quad$ doi: https://doi.org/10.54112/bcsrj.v2020i1.33] 
Table 1. Anti-bacterial activity of Citrullus colocynthis fruit extract against bacterial species

\begin{tabular}{ccccccc}
\hline \multicolumn{7}{c}{ Concentration $(\mathbf{m g} / \mathbf{m l})$ and zone of inhibition (mm) } \\
microorganisms & $\mathbf{2 5}$ & $\mathbf{5 0}$ & $\mathbf{7 5}$ & $\mathbf{1 0 0}$ & Positive control & Negative control \\
\hline Staphylococcus aureus & 11 & 16 & 19 & 22 & 24 & 0 \\
Bacillus subtilis & 13 & 15 & 16 & 21 & 24 & 0 \\
Pseudomonas aeruginosa & 12 & 13 & 18 & 19 & 25 & 0 \\
Klebseilla pneumonia & 15 & 17 & 15 & 19 & 28 & 0 \\
\hline
\end{tabular}

Table 2. Antifungal activity of Citrullus colocynthis fruit against fungal species

\begin{tabular}{ccccccc}
\hline \multicolumn{7}{c}{ Concentration $\mathbf{( m g} / \mathbf{m l})$ and zone of inhibition (mm) } \\
microorganisms & $\mathbf{2 5}$ & $\mathbf{5 0}$ & $\mathbf{7 5}$ & $\mathbf{1 0 0}$ & Positive control & Negative control \\
\hline Candida albicans & 9 & 13 & 15 & 18 & 21 & 0 \\
Aspergillus fumigatus & 10 & 16 & 15 & 19 & 23 & 0 \\
Aspergillus niger & 12 & 15 & 22 & 23 & 22 & 0 \\
Fuserium oxysporum & 10 & 13 & 14 & 15 & 22 & 0 \\
\hline
\end{tabular}

Table 3. Antibacterial activity of root extract of Citrullus colocynthis

\begin{tabular}{ccccccc}
\hline \multicolumn{7}{c}{ Concentration $\mathbf{( m g / m l )}$ and zone of inhibition (mm) } \\
microorganisms & $\mathbf{2 5}$ & $\mathbf{5 0}$ & $\mathbf{7 5}$ & $\mathbf{1 0 0}$ & Positive control & Negative control \\
\hline Staphylococcus aureus & 14 & 20 & 20 & 22 & 28 & 0 \\
Bacillus subtilis & 11 & 15 & 21 & 23 & 26 & 0 \\
Pseudomonas aeruginosa & 7 & 12 & 20 & 20 & 20 & 0 \\
Klebseilla pneumonia & 13 & 15 & 18 & 21 & 20 & 0 \\
\hline
\end{tabular}

Table 4. Antifungal activity of fungal species against root extract of Citrullus colocynthis

\begin{tabular}{ccccccc}
\hline \multicolumn{7}{c}{ Concentration (mg/ml) and zone of inhibition (mm) } \\
microorganisms & $\mathbf{2 5}$ & $\mathbf{5 0}$ & $\mathbf{7 5}$ & $\mathbf{1 0 0}$ & Positive control & Negative control \\
\hline Candida albicans & 9 & 14 & 17 & 19 & 19 & 0 \\
Aspergillus fumigatus & 11 & 15 & 18 & 21 & 21 & 0 \\
Aspergillus niger & 7 & 11 & 19 & 20 & 20 & 0 \\
Fuserium oxysporum & 18 & 20 & 18 & 22 & 21 & 0 \\
\hline
\end{tabular}

Table 5. Antibacterial activity of seed extract of Citrullus colocynthis

\begin{tabular}{ccccccc}
\hline \multicolumn{7}{c}{ Concentration $(\mathbf{m g} / \mathbf{m l})$ and zone of inhibition (mm) } \\
microorganisms & $\mathbf{2 5}$ & $\mathbf{5 0}$ & $\mathbf{7 5}$ & $\mathbf{1 0 0}$ & Positive control & Negative control \\
\hline Staphylococcus aureus & 10 & 11 & 14 & 15 & 20 & 0 \\
Bacillus subtilis & 11 & 8 & 20 & 22 & 20 & 0 \\
Pseudomonas aeruginosa & 9 & 13 & 14 & 17 & 7 & 0 \\
Klebseilla pneumonia & 11 & 13 & 15 & 20 & 21 & 0 \\
\hline
\end{tabular}

\begin{tabular}{ccccccc}
\hline \multicolumn{7}{c}{ Table 6. Antifungal activity of seed extract of Citrullus colocynthis } \\
\hline \multicolumn{7}{c}{ Concentration $\mathbf{( m g / m l )}$ and zone of inhibition (mm) } \\
microorganisms & $\mathbf{2 5}$ & $\mathbf{5 0}$ & $\mathbf{7 5}$ & $\mathbf{1 0 0}$ & Positive control & Negative control \\
\hline Candida albicans & 11 & 12 & 14 & 19 & 19 & 0 \\
Aspergillus fumigatus & 12 & 15 & 16 & 20 & 20 & 0 \\
Aspergillus niger & 14 & 17 & 17 & 22 & 21 & 0 \\
Fuserium oxysporum & 15 & 19 & 19 & 21 & 21 & 0 \\
\hline
\end{tabular}

\section{Discussion}

The effect of Citrullus colocynthis plant extracts using fruit pulp, seeds and roots at different concentrations $25 \mathrm{mg} / 1 \mathrm{ml}$ DMSO, $50 \mathrm{mg} / 1 \mathrm{ml}$ DMSO, $75 \mathrm{mg} / 1 \mathrm{ml}$ DMSO, and $100 \mathrm{mg} / 1 \mathrm{ml}$ DMSO against the bacterial and fungal strains (Marzouk et al., 2009; Marzouk et al., 2010). All the organisms showed sensitivity against the extracts but the zones of inhibition were smaller as compared to other ones in the seed extracts of the plant. The zones of inhibition were greater in the gram-positive bacteria (S. aureus and B. subtilis) as compared to the gramnegative bacteria and zones of inhibition were also increased by increasing the concentrations of the extracts (Jayaraman et al., 2009; Mehrzadi et al., 2016). Gram-negative bacteria Pseudomonas aeruginosa showed sensitivity against the ethanolic extract of C. colocynthis contrary (Salehi et al., 2019) who studied soil bacteria at the concentration of $10 \%$. As much as antifungal results are concerned, all the [Citation: Hameed, B., Ali, Q., Hafeez, M.M., Malik, A. (2020). Antibacterial and antifungal activity of fruit, seed and root extracts of Citrullus colocynthis plant. Biol. Clin. Sci. Res. J., 2020: 33. doi: https://doi.org/10.54112/bcsrj.v2020i1.33] 
extracts showed good results against all the fungal strains especially anticandidal activity (C. albicans), the efficiency of extracts activity was increased by increasing the concentration of the extracts. The potential of activity of each organ is dependent on plant extract and which is a crude mixture composed of compounds having activity and non-activity (Sharififar et al., 2007; Yazit et al., 2019). The plant organ and the nature of solvent play an important role in the activity of the extract in given organisms. The polarity and non-polarity factor in the solvents, used in the preparation of extracts affects the efficiency of extracts at greater extent (Dastmalchi et al., 2007; Song et al., 2015).

\section{Conclusion}

The study concluded that Citrullus colocynthis plant has a good efficiency against common human pathogens when prepared in ethanol and its activity also increased by increasing the concentrations of the extracts. This study is based on plant extract from three different organs (fruit pulp, seed and root), on four bacterial and four fungal species and including Gram positive and Gram negative bacteria also Candidal species (C. albicans). The results presented in the study showed that natural products examined can be a better source for the creation of modern ways to treat infections in gastrointestinal, skin and pulmonary infections.

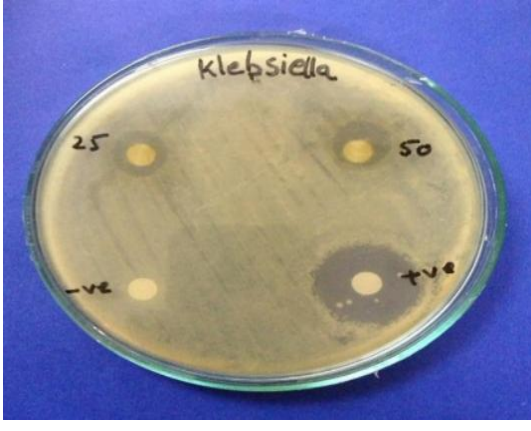

C. colocynthis fruit pulp (K. pneumonia) (Disc diffusion method)

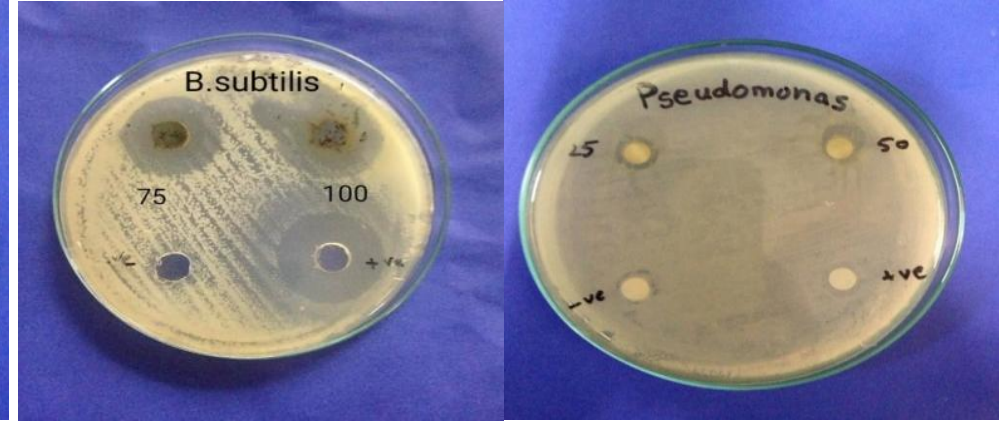

C. colocynthis root (B.subtilis) (Well diffusion method)
C. colocynthis seed (P.aeruginosa) (Disc diffusion method)

$\begin{array}{lll}\text { C. colocynthis root (S.aureus) } & \text { C. colocynthis fruit pulp (A. niger) } & \text { C. colocynthis fruit pulp (F. oxysporum) }\end{array}$ (Disc diffusion method)
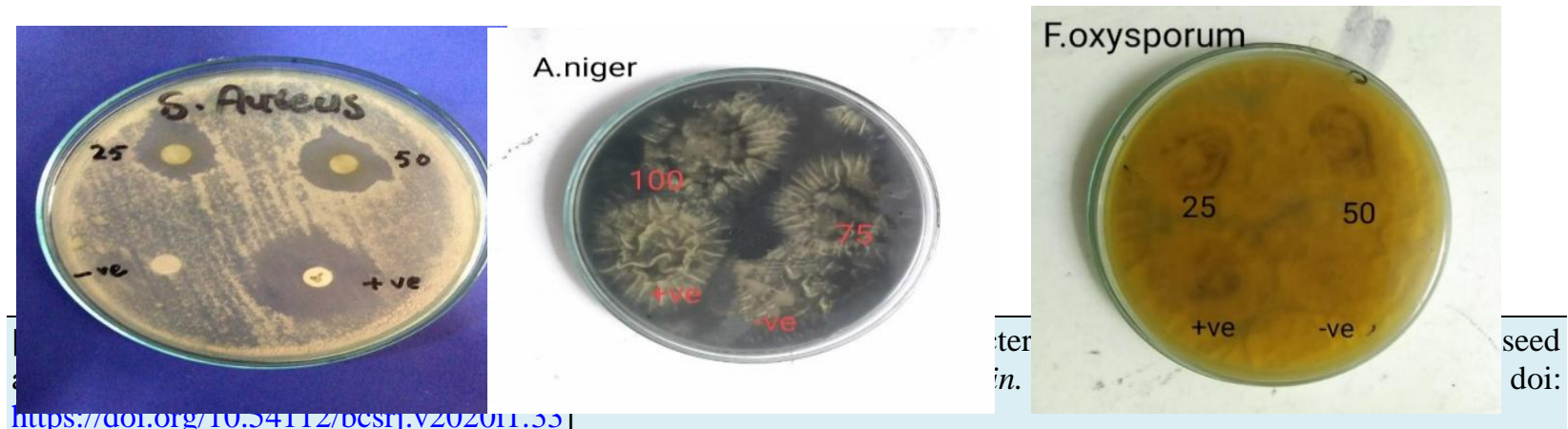
Figure 1. Antibacterial and antifungal activities of $C$. colocynthis plant extracts

\section{Conflict of interest}

The authors declared absence of conflict of interest.

\section{References}

Bernard, S. A., and Olayinka, O. A. (2010). Search for a novel antioxidant, antiinflammatory/analgesic or anti-proliferative drug: Cucurbitacins hold the ace. Journal of Medicinal Plants Research 4, 2821-2826.

Bhasin, A., Singh, S., and Garg, R. (2020). Nutritional and medical importance of Citrullus colocynthis-A review. Plant Archives 20, 3400-3406.

Dastmalchi, K., Dorman, H. D., Koşar, M., and Hiltunen, R. (2007). Chemical composition and in vitro antioxidant evaluation of a watersoluble Moldavian balm (Dracocephalum moldavica L.) extract. LWT-Food Science and Technology 40, 239-248.

Davidovich-Rikanati, R., Shalev, L., Baranes, N., Meir, A., Itkin, M., Cohen, S., Zimbler, K., Portnoy, V., Ebizuka, Y., and Shibuya, M. (2015). Recombinant yeast as a functional tool for understanding bitterness and cucurbitacin biosynthesis in watermelon (Citrullus spp.). Yeast 32, 103-114.

Dhakad, P. K., Sharma, P. K., and Kumar, S. (2017). A review on phytochemical studies and biological potential of Citrullus colocynthis (L.) Schrad (Cucurbitaceae). J Bioeng Biosci 5, 55-64.

Dhanotia, R., Chauhan, N. S., Saraf, D. K., and Dixit, V. K. (2011). Effect of Citrullus colocynthis Schrad fruits on testosterone-induced alopecia. Natural product research 25, 1432-1443.

Gurudeeban, S., Satyavani, K., and Ramanathan, T. (2010). Bitter apple (Citrullus colocynthis): An overview of chemical composition and biomedical potentials. Asian Journal of Plant Sciences 9, 394.

Hussain, A. I., Rathore, H. A., Sattar, M. Z., Chatha, S. A., Sarker, S. D., and Gilani, A. H. (2014). Citrullus colocynthis (L.) Schrad (bitter apple fruit): A review of its phytochemistry, pharmacology, traditional uses and nutritional potential. Journal of ethnopharmacology 155, 54-66.

Jayaraman, R., Shivakumar, A., Anitha, T., Joshi, V., and Palei, N. (2009). Antidiabetic effect of petroleum ether extract of Citrullus colocynthis fruits against streptozotocin- induced hyperglycemic rats. Rom J Biol Plant Biol 4, 127-34.

Kapoor, M., Kaur, N., Sharma, C., Kaur, G., Kaur, R., Batra, K., and Rani, J. (2020). Citrullus colocynthis an Important Plant in Indian Traditional System of Medicine. Pharmacognosy Reviews 14, 23.

Kaushik, U., Aeri, V., and Mir, S. R. (2015). Cucurbitacins-an insight into medicinal leads from nature. Pharmacognosy reviews 9, 12.

Kouadri, I., and Satha, H. (2018). Extraction and characterization of cellulose and cellulose nanofibers from Citrullus colocynthis seeds. Industrial Crops and Products 124, 787-796.

Mehrzadi, S., Shojaii, A., Pur, S. A., and Motevalian, M. (2016). Anticonvulsant activity of hydroalcoholic extract of Citrullus colocynthis fruit: involvement of benzodiazepine and opioid receptors. Journal of evidence-based complementary \& alternative medicine $\mathbf{2 1}$, NP31-NP35.

Onyeji, C. O., Igbinoba, S. I., and Olayiwola, G. (2017). Therapeutic potentials and cytochrome P450-mediated interactions involving herbal products indicated for diabetes mellitus. Drug metabolism letters 11, 74-85.

Pravin, B., Tushar, D., Vijay, P., and Kishanchnad, K. (2013). Review on Citrullus colocynthis. Int. J. Res. Pharm. Chem 3, 46-53.

Rezai, M., Davoodi, A., Asori, M., and Azadbakht, M. (2017). Cytotoxic activity of citrullus colocynthis (L.) schrad fruit extract on gastric adenocarcinoma and breast cancer cell lines. Int J PhaInt J Pharm Sci Rev Res 45, 175-178.

Riaz, H., Chatha, S. A. S., Hussain, A. I., Bukhari, S. A., Hussain, S. M., and Zafar, K. (2015). Physico-chemical characterization of bitter apple (Citrullus colosynthis) seed oil and seed residue. Int. J. Biosci 6, 283-292.

Salehi, B., Capanoglu, E., Adrar, N., Catalkaya, G., Shaheen, S., Jaffer, M., Giri, L., Suyal, R., Jugran, A. K., and Calina, D. (2019). Cucurbits plants: A key emphasis to its pharmacological potential. Molecules 24, 1854.

Sharififar, F., Moshafi, M., Mansouri, S., Khodashenas, M., and Khoshnoodi, M. (2007). In vitro evaluation of antibacterial and antioxidant activities of the essential oil and methanol extract of endemic Zataria multiflora Boiss. Food control 18, 800-805.

[Citation: Hameed, B., Ali, Q., Hafeez, M.M., Malik, A. (2020). Antibacterial and antifungal activity of fruit, seed and root extracts of Citrullus colocynthis plant. Biol. Clin. Sci. Res. J., 2020: $33 . \quad$ doi: https://doi.org/10.54112/bcsrj.v2020i1.33] 
Song, F., Dai, B., Zhang, H.-Y., Xie, J.-W., Gu, C.Z., and Zhang, J. (2015). Two new cucurbitane-type triterpenoid saponins isolated from ethyl acetate extract of Citrullus colocynthis fruit. Journal of Asian natural products research 17, 813-818.

Yazit, S., Nemmiche, S., Amamou, F., Meziane, R., and Chabane-Sari, D. (2019). Antihyperlipidemic Effect of Fatty Acids Methyl Esters (FAMEs) of Citrullus colocynthis in High-Fat Diet Induced Obesity in Rats. Phytothérapie.

\section{(c) (7) (5)}

Open Access This article is licensed under a Creative Commons Attribution 4.0 International License, which permits use, sharing, adaptation, distribution and reproduction in any medium or format, as long as you give appropriate credit to the original author(s) and the source, provide a link to the Creative Commons licence, and indicate if changes were made. The images or other third party material in this article are included in the article's Creative Commons licence, unless indicated otherwise in a credit line to the material. If material is not included in the article's Creative Commons licence and your intended use is not permitted by statutory regulation or exceeds the permitted use, you will need to obtain permission directly from the copyright holder. To view a copy of this licence, visit http://creativecommons.org/licen ses/by/4.0/.

(C) The Author(s) 2020

[Citation: Hameed, B., Ali, Q., Hafeez, M.M., Malik, A. (2020). Antibacterial and antifungal activity of fruit, seed and root extracts of Citrullus colocynthis plant. Biol. Clin. Sci. Res. J., 2020: 33. doi: https://doi.org/10.54112/bcsrj.v2020i1.33] 